\title{
PENERAPAN METODE FGD (FOCUS GROUP DISCUSION) DALAM PENGEMBANGAN KETERAMPILAN WIRAUSAHA MAHASISWA MELALUI KARAKTERISTIK KEWIRAUSAHAAN
}

\author{
Novita Delima Putri \\ Dosen Program Studi Pendidikan Ekonomi Universitas Indraprasta PGRI \\ E-mail : novita111100@yahoo.com
}

\begin{abstract}
Abstrak : Wirausaha merupakan salah satu upaya mengatasi pengangguran dan kemiskinan. Pergeseran pandangan profesi mahasiswa setelah lulus yang awalnya karyawan menjadi pengusaha, harus dibarengi dengan usaha memupuk semangat dan keterampilan wirausaha (entrepreneurial skill) mereka. Usaha tersebut dilakukan dalam bentuk wadah formal berupa mata kuliah kewirausahaan. Penelitian ini mempunyai tujuan mengidentifikasi entrepreneurial skill mahasiswa peserta kuliah kewirausahaan dan pengusaha, sehingga dapat disusun modeldan modul pembelajaran yang tepat. Metode penelitian yang digunakan adalah pendekatan kualitatif. Pengumpulan data dilakukan mellaui kuisioner dan diskusi kelompok terarah (FGD) serta review mendalam (in-depth review), terhadap sampel yang diambil secara purposive. Hasil penelitian ini mendukun penelitian sebelumnya bahwa ada terdapat enam karakkteristik yang dimiliki wirausaha yaitu, Percaya diri, berorientasi pada tugas dan hasil, pengambilan resiko, kepemimpinan, keorisinilan, dan berorientasi ke masa depan. Terdapat perbedaan keteraampilan yang dimiliki mahasiwa dan pengusaha, untuk menyelaraskannya perlu diterapkan metode pembelajaran yang member kesempatan kepada mahasiswa untuk bias mengalami sendiri situasi wirausaha dengan mentor para pengusaha.
\end{abstract}

\section{Kata kunci: keterampilan wirausaha, pengusaha, karakteristik, FGD}

\section{PENDAHULUAN}

Penganguran merupakan masalah terbesar yang dihadapi oleh bangasa Indonesia saat ini. Sampai saat ini data menunjukkan bahwa tingkat pengangguran terbuka sarjana dan lulusan diploma masih sangatkah tinggi yaitu sebesar 7.5 persen untuk diploma dan sarjana 6.95 persen, dengan jumlah pengangguran secara nasional mencapai sekitar 7.6 juta orang (BPS,2012). Yang menjadi penyebab fatktor utama adalah keterbatasan kesempatan kerja bagi para pencari kerja, dalam hal ini berarti jumlah lowongan pekerjaan masih sangat terbatas. Lulusan perguruan tinggi kebanyakan masih mempunyai pola piker bahwa setelah lulus kuliah orientasi nya adalah bekerja pada di perusahaan, bukan sebagai pencipta pekerjaan, hal ini didorong pola piker menjadi pegawai adalah pilihan yang paling aman (comfort zone), tidak berisiko seperti halnya berwirausaha. Pemerintah mempunyai program dalam mengatasi masalah oengangguran ini 
dengan mendorong terciptanya lapangan usaha melalui semangat enterpreneuship, karena pentingya kewirausahaan sebagai mesin penggerak perekonomian. Maka oleh karena itu pembelajaran kewirausahaan dilakukan disemua institusi pendidikan dibawah instasi pemerintah, masyarakat umum serta siswa untuk mengembangkan model pengembangan pendidikan kewirausahaan yang akan memberikan keterampilan bagi siswa nantinya. Perguruan tinggi telah melakukan pengembangan semangat kewirausahaan, yang salah satunya dengan adanya kurikulum kewirausahaan. Menurut Charney dan Libercap (2000) , lulusan program kewirausahaan mempunyai kemampuan tiga kali lebih besar untuk mendapat memulai bisnis baru. Hal ini kemudian menunjukkan bahwasannya kewirausahaan merupakan pengetahuan penting bagi lulusan perguruan tinggi.

Dari beberapa metodologi pendekatan dalam kewirausahaan telah disumbangkan oleh beberapa peneliti dari berbagai disiplin ilmu. Pendapat dari Charney dan Libercap (2000) menyatakan bahwa signifikan dari pendidikan kewirausahaan pada umumnya merupakan pendorong dalam pengambilan resiko dan penciptaan bisnis baru, sehingga akan memberikan dampak positif yang signifikan bagi para lulusan untuk menjadi wirausaha yaitu pada pendapatan mereka, sehingga akan menciptakan usaha- usaha kecil yang baru. Hal ini dapat menjadikan media dalam transfer ilmu pengetahuan dari universitas kepada dunia usaha. Investasi dalam kewirausahaan dapat menciptakan lapangan kerja dan merangsang produktivitas. Oleh karena itu pendidikan kewirausahaan membutuuhkan alokasi waktu dan modal yang cukup.

Pendidikan kewirausahaan yang terintegrasi merupakan kolaborasi antara pengembangan pola piker kewirausahaan, kemampuan berwirausaha (entepreunerial skills) serta menjadi sukses yang ditandai dengan melakukan transmisi dari semangat kewirausahaan menjadi entrepreneurship behavior (perilaku kewirausahaan). Namun masih belum adanya kejelasan apakah pendidikan tinggi sebagai emkanisme transmisi sukses dalam promosi kewirasuahaan. Dalam mekanisme ini mahasiswa memerlukan tahapanmenciptakan inovasi dan menciptakan bisnis (start up business). Proses transmisi ini memerlukan dukungan akademisi dalam pengembangan pengetahuan kewirausahaan serta pendampingan dari dunia usaha itu sendiri.Menurut Kirby (2002) pendidikan kewirausahaan berbeda dari manajemen tradisional, yang masih menghambat kualitas kewirausahaan dan ketarmpilan. Pendidikan keterampilan membutuhkan metode pengajaran yang berbeda. Untuk mengembangkan metode pengajaran kewirausahaan yang tepat, diperlukan identifikasi entrepreneurial skill dari mahasiswa dan pengusaha.

Riset ini mengidentifikasi entrepreneurial skill mahasiswa dan pengusaha dalam rangka peningkatan entrepreneurial skill mahasiswa, sehingga dapat dijadikan dasar penyusunan model dan modul kewirausahaan dimasa yang akan datang.

\section{KAJIAN PUSTAKA \\ Wirausaha}

Sampai saat ini konsep kewirausahaan masih terus berkembang. Wirausaha adalah seseorang yang bebas dan memiliki kemampuan untuk hidup mandiri dalam menjalankan kegiatan usahanya atau bisnisnya ataupun hidupnya. Bebas merancang, menentukan, mengelolah, mengendalikan usahanya. 
Sedangkan kewirausahaan adalah suatu sikap, jiwa dan kemampuan untuk menciptakan sesuatu yang baru yang sangat bernilai dan berguna bagi dirinya dan orang lain. Kewirausahaan merupakan sikap mental dan jiwa yang selalu aktif dan kreatif berdaya, bercipta, berkarya dan bersahaja dan berusaha dalam rangka meningkatkan pendapatan dalam kegiatan usahanya atau kiprahya. Seseorang yang memiliki sikap dan jiwa wirausaha selalu tidak puas dengan apa yang telah dicapainya. Wirausaha adalah orang yang trampil memanfaatkan peluang dalam mengembangkan usahanya dengan tujuan untuk meningkatkan kehidupannya (setyorini, 2010).

Schumpter (1934) menyatakan bahwa kewirausahaan (entrepreneurship) merupakan tindakan melakukan kreatifitas pada lima hal yaitu; 1) pengenalan produk baru, 2) pengenakan metode baru, 3) membuka pasar baru, 4) penaklukan sumber daya baru dan 5) membuat usaha baru di industry. Kewirausahaan merupakan hal yang penting dikarenakan keterkaitannya dengan system ekonomi dan mengatasi pengangguran.

Wirausaha adalah seseorang pembuat keputusan yang membantu terbentuknya system ekonomi perusahaan yang bebas. Karir kewirausahaan dapat mendukung kesejahteraan masyarakat, menghasilkan imbalan financial yang nyata. Wirausaha di berbagai industry membantu perekonomian dengan menyeediakan lapangan pekerjaan dan memproduksi barang dan jasa bagi konsumen dalam negeri maupun luar negeri. Meskipun perusahaan raksasa menarik perhatian banyak public akan tetapi bisnis kecil dan kegiatan kewirausahaannya setidaknya memberikan andil nyata bagi kehidupan social dan perekonomian dunia.

\section{Karakteristik Wirausaha}

Karakteristik wirausaha menurut Meredith, et.al., dalam Suryana (2001) adalah sebagai berikut :

Tabel 1. Karakteristik dan Watak Wirausaha

\begin{tabular}{|l|l|}
\hline \multicolumn{1}{|c|}{ KARAKTERISTIK } & \multicolumn{1}{|c|}{ WATAK } \\
\hline Percaya Diri & $\begin{array}{l}\text { Keyakinan, ketidaktergantungan, } \\
\text { individualistis, dan optimism }\end{array}$ \\
\hline Berorientasi pada tugas dan hasil & $\begin{array}{l}\text { Kebutuha untuk berprestasi, } \\
\text { berorientasi laba, ketekunan dan } \\
\text { ketabahan, tekad kerja keras, } \\
\text { mempunyai dorongan kuat, energetic } \\
\text { dan inisiatif }\end{array}$ \\
\hline Pengambilan Resiko & $\begin{array}{l}\text { Kemampuan untuk mengambil resiko } \\
\text { yang wajar dan suka tantangan }\end{array}$ \\
\hline Kepemimpinan & $\begin{array}{l}\text { Perilaku sebagai pemimpin, bergaul } \\
\text { dengan orang lain, menanggapi } \\
\text { saran-saran dan kritik }\end{array}$ \\
\hline Keorisinilan & Inovatif dan kreatif serta fleksibel \\
\hline Berorientasi ke masa depan & Pandangan ke depan, perspektif \\
\hline
\end{tabular}

Proses Pembelajaran Kewirausahaan (Entrepreunerial Learning) 
Dalam teori siklus pembelajaran, Munford (1995) menyatakan bahwa pembelajaran didapat dari proses pembelajaran atas pengalaman yang didapat dalam aktivitas sehari-hari yang kemudian disimpulkan dan menjadi konsep maupun system nilai yang dipergunakan untuk keberhasilan dimasa yang akan datang. Hall (1996) menyatakan bahwa dalam jangka pendek pembelajaran akan merubah sikap dan kinerja seseorang, sedangkan dalam jangka panjang mampu menumbuhkan identitas dan daya adaptabilitas seseorang yang sangat penting bagi keberhasilannya. Cope dan Watt (2000) menyatakan bahwa kejadian kritis (critical-incident) yang dialami wirausaha dalam kegiatan usahanya sehari-hari mengandung muatan emosional yangs angta tinggi dan pembelajaran tingkat tinggi. Cope dan Watt menekankan pentingnya pembimbingan (mentoring) untuk menginterprestasikan kejadian kritis yang dihadapi sebagai pembelajaran, sehingga hasil pembelajaranya menjadi efektif.

Sulivan (2000) menekankan pentingnya client-mentor matching dalam keberhasilan pembimbingan. Ia menyatakan bahwa pengetahuan, keterampilan, dan pembelajaran dapat di fasilitasi ketika dibutuhkan wirausaha. Dengan memperhatikan tingkat siklus hidup wirausaha. Lebih jauh Rae (2000) menggambarkan bahwa pengembanagn kemampuan wirausaha dipengaruhi oleh motivasi, nilai-nilai individu, kemampuan, pembelajaran, hubungan-hubungan, dan sasaran yang diinginkan. Sementara Minniti dan Bygrave (2001) membuktikan dalam model dinamis pembelajaran wirausaha, bahwa kegagalan dan keberhasilan wirausaha akan memperkaya dan memperbaharui stock of knowledge serta sikap wirausaha sehingga ia menjadi lebih mampu dalam berwirausaha.

Dalam kaitannya dengan upaya untuk mempertahankan usaha, seorang wirausahawan memrlukan suatu strategi positioning yang kuat serta konsisten dalam suatu lingkungan persaingan yang dinamis. Hal ini memerlukan suatu perbaikan yang berkelanjutan untuk mengelola perubahan tersebut agar efeltif sehingga diperlukan suatu proses pembelajaran baik single-loop learning untuk memperkuat posisi saat ini maupun double-loop learning untuk menemukan landasan kokoh guna membangun keunggulan bersaing. Wright (1997) menyebutkan bahwa "akumulasi pembelajaran" merupakan salah satu harta tak berwujud yang menjadikan suatu kapabilitas individu atau perusahaan yang tidak dapat ditiru (inmitable) terutama pengetahuan teknis yang tidak kentara(tacit knowledge).

Pendidikan dan latihan, mentoring dan belajar dari pengalaman merupakan factor pembentuk pembelajaran kewirausahaan yang signifikan. Hal ini sesuai dengan pendapat beberapa ahli tentang pembelajaran wirausaha (Rae, 2000; Minniti dan Bygrave, 2001), proses pendidikan dan pelatihan (Ulrich dn Cole, 1987; Robinson dan Sexton, 1994; Gibb,1997; Leitch dan Horrisaon, 1999) maupun pembelajaran wirausaha dari pengalaman (Henderson,1993; Rae, 2000; Cope dan Watrs, 2003). Pembelajaran dapat dipandang sebagai proses perubahan dan pembentukan pengetahuan, ketarampilan, sikap dan kemampuan seseorang wirausahawan, baik melalui pendidikan, pelatihan, mentoring ataupun pengalaman. 


\section{METODE ANALISIS}

Penelitian ini menggunakan desain penelitian kualitatif untuk mengidentifikasi siswa keterampilan kewirausahaan dibandingkan dengan keterampilan yang biasa dimiliki pengusaha. Pengumpulan data dilakukan melalui kuesioner dan kelompok terfokus (FGD) dan mendalam review. Sampel diambil secara porposional. Siswa harus memenuhi kriteria ini: mahasiswa semester 5, bergabung dalam kursus kewirausahaan. Dan kriteria bagi pengusaha dianggap sebagai pengusaha sukses dari beberapa bidang usaha. Variabel dari penelitian ini terdiri dari ENAM Karakteristik, percaya diri, orisinalitas, tugas dan berorientasi hasil, pengambil risiko, berorientasi masa depan, kepemimpinan.

\section{HASIL DAN PEMBAHASAN}

Penelitian ini melibatkan 30 responden yang terdiri dari mahasiswa semester 5 yang sedang mengambil mata kuliah kewirausahaan dan entrepreneur yang terlibat dalam riset ini merupakan perwakilan komunitas pengusaha muda di Bekasi yang terbilang sukses berjumlah 7 orang, karena memiliki usaha yang eksis lebih dari 3 tahun dengan omset cukup tinggi. FGD dilakukan diawal semester ketika mahasiswa masih belum menerima materi tentang kewirausahan. Data awal yang didapat melalui kuisioner menunjukkan statistic sebagai berikut :

Jenis kelamin didominasi laki-laki sebanyak $70 \%$, dengan usia rata-rata 20 tahun. $89 \%$ mahasiswa minat pada usaha di bidang usaha dagang namun hanya $40 \%$ yang telah memiliki pengalaman kerja atau wirausaha selama kurang lebih setahun. Mahasiswa ini termasuk aktif karena menjadi pengurus maupun panitia kegiatan yang dilakuakn unit kegiatan mahasiswa. Dilihat dari latar belakang keluarga, sebagan memiliki orang tua yang berprofesi sebagai wirausaha sebagian lagi belerja sebagai PNS/TNI/BUMN/POLRI.

Adapun entrepreneur yang berkesempatan hadir dalam FGD merupakan pengusaha yang bergerak dibidang bimbel, fashion, asesories handphone, kuliner serta catering.

Hasil FGD menunjukkan bahwa pengusaha yang hadir memiliki enam karakteristik entrepreneur yaitu, self confidence, origanility, task and result oriented, risk taker, future oriented da leadership. Sedangkan mahasiswa memiliki cikal bakal karaktersitik yang sama dengan para pengusaha, namum dalam tingkat kematangan yang berbeda dengan para pengusaha.

Berdasarkan hasil FGD setidaknya dapat dikemukakan bahwa kebanyakan wirausaha yang sekarang berhasil karena mempunyai ciri - ciri :

1. Keberanian, yakni berani untuk memulai usaha yang ingin dilakukan, karena berani memulai merupakan kunci sukses. Berani untuk memulai merupakan separuh dari keberhasilan, tidak berani memulai dapat dipastikan tidak akan berhasil. Untuk menjadi pengusaha menurut mereka harus berani dulu memulai, setelah itu memiliki keterampilan yang diperlukan sebagai usahawan. Merupakan anggapan yang tidak tepat apabila ingin menjadi usahawan harus terampil dulu, karena menurut pendapat dalam FGD dengan memulain usaha akan dapat memenfaatkan pihak lain yang terampil dalam bidang-bidnag tertentu sebagai mitra usahanya.

2. Motivasi, yani kayakinan dan dorongan yang kuat untuk melaksanakan kegiatan usaha sangat diperlukan bagi seorang wirausaha. Umumnya mereka melihat bahwa terjadi perubahan yang serba cepat dan penuh ketidakpastian 
dalam segala aspek.sebagai seorang wirausahawan perubahan-perubahan tersebut harus menjadi motivasi untuk bias mengatasi dan melewatinya, bukan justru menjadikannya hambatan.

3. Optimis, keberhasilan seseorang usahawan dalam menggeluti bisnisnya terletak pada rasa optimism yang sangat tinggi. Dalam situasi perekonomian yang sesulit apapun diperlukan tekad yang kuat untuk tetap menggeluti bisnisnya. Sebab dengan tekad yang kuat akan termotivasi untuk memanfaatkan setiap peluang bisnis yang ada untuk mewujudkan keberhasilan usahanya.

4. Berani gagal, ungkapan berani menanggung kegagalan merupakan awal dari keberhasilan bukan slogan semata. Ungkapan ini banyak benarnya. Sebagai usahawan dituntuk untuk tidak mudah menyerah, tetapi harus berani jatuh bangun dalam membangun bisnisnya

5. Nyontek bisnis, hal tersebut bukan merupakan sesuatu yang tabu. Dalam dunia bisnis nyontrk bisnis merupakan hal yang sangat lumrah dan kreatif. Bagi usahawan yang baru memulai masuk usaha bisnis tidak sedikit awalnya adalah menyontek. Kemudian dengan tambahan keterampilan mereka akan berusaha mengembangkan bisnisnya yang akhirnya bias berhasil.

Berangkat ari ciri-ciri tersebut maka setidaknya terdapat dua kelompok wirausahawan yakni :

1. Innovating Entrepreneurship, yakni pengusaha yang secara agresif dan trampil mempraktekkan transformasi-transformasi atraktif. Mereka umumnya melakukan inovasi atau terobosan - terobosan baru dalam memulai usahanya.

2. Imitative Entrepreneurship, yaitu pengusaha yang meniru inovasi yang berhasil dari para innovating entrepreneur.

Adapun faktor-faktor yang mendukung mereka bisa menjadi wirausahawan antara lain :

1. Faktor individual/personal, yakni pengaruh pengalaman atau cita-cita dari kecil hingga dewasa

2. Suasana Kerja, suasana yang memberikan peluang untuk berwirausaha karena adanya kebutuhan dari rekan kerja anak barang dan jasa tertentu.

3. Pendidikan, latar belakang pendidikan umumnya ikut mewarnai seseorang menjadi wirausaha.

4. Lingkungan Keluarga, umumnya keluarga wirausaha juga cenderung untuk melahirkan wirausahawan baru.

5. Lingkungan dan pergaulan, seseorang yang serig berada pada lingkungan bisnis umumnya akan besar ketertarikannya untuk menggeluti bidang usaha yang di akrab

6. Keterpaksaan dan keadaan yang mengharuskan untuk menjadi wirausaha, umumnya dihadapi oleh mereka yang mendapatkan limpahan bisnis dari orang tua atau keluarga.

Berdasarkan pengalaman para usahawan peserta FGD dapat dikemukakan bahwa untuk menjadi entrepreneur diperlukan proses pembentukan diri yang mencakup : 
1. Mengenal, memahami dan mengerti kewirausahaan, proses ini biasanya akan memotivasi seseorang untuk menjadi wirausahawan

2. Memperisiapkan diri dan merencanakan bisnis yang akan dilakukan. Proses ini mencakup memahami, dan merancang kegiatan usaha sesuai dengan peluang dan kemampuan yang dimiliki.

3. Memulai, menjalankan, mengelola, dan mengembangkan bisnis

Dengan demikian untuk menjadi wirausahawan setidaknya di butuhkan pengetahuan dasar yang mencakup :

1. Kemampuan membaca peluang pasar

2. Kemampuan menyusun rencana bisnis

3. Kemampuan memberdayakan SDM

4. Kemampuan berorganisasi

5. Kemampuan mencari sumber permodalan

6. Kemampuan dalam kepemimpinan

Dalam menjalankan praktek kewirausahaan, secara umum melalui tahap tahap sebagai berikut :

1. Persiapan. Tahap ini merupakan tahap dimana seseorang yang akan melakukan kegiatan usaha mempersiapkan segala sesuatu yang diperlukan. Kegiatan pada tahap ini dimulai dengan melihat peluang yang ada, memilih kegiatan usaha yang sesuai, dan menetukan apakah akan bekerja sendiri atau bergabung.

2. Pelaksanaan. Tahap ini seorang calon wirausaha mencoba mengelola berbagai aspek sumberdaya, seperti pembiyaan, kepemilikan, SDM, organisasi dan kepemimpinan.

3. Evaluasi dan Analisis. Tahap ini mencakup kegiatan evaluasi dan analisa perkembangan yang dicapai untuk diputuskan tindak lanjutnya sesuai dengan kondisi yang dihadapi.

4. Pengembangan Usaha. Berdasarkan hasil evaluasi dan analisis akan bisa diputuskan untuk mempertahankan, mengembangkan, atau memperluas usaha

Setidaknya terdapat lima aspek penting yang dapat diambil berdasarkan indentifikasiwirausahawan yang berhasil antara lain memiliki :

1. Kemampuan

2. Keterampilan

3. Kreatifitas

4. Keteguhan

5. Keberuntungan

Disertai dengan sikap jujur, bertanggung jawab, dan senatiasa taat berdoa.

\section{SIMPULAN DAN REKOMENDASI}

Berdasarkan hasil penelitian menunjukkan bahwa untuk menjadi wirausaha siperlukan sifat confidance, end result and tasks orientad, risk taking, leadership, originality, and oriented to the future. Mahasiswa perlu dibekali sifat yang diperlukan sebagai pengusaha, hal ini dengan melakukan pembaharuan kurikulum, salah satunya adalah melalui penyempurnaan isi/ materi mata kuliah kewirausahaan. 
Setidaknya terdapat dua golongan pengusaha/calon pengusaha yang melalui aktivitas bisnisnya, yakni :

Innovating, merupakan pengusaha yang memulai bisnisnya melalui kreasi dan penciptaan baru. Kelompok ini berusaha melalui usahanya melalui kegiatan penciptaan barang baru, yang sama sekali baru bagi dirinya maupun baru bagi pasar, atau pengusaha berusaha menciptakaan pasar yang baru untuk barang sudah ada.

Imitative, kelompok pengusaha ini memulai kegiatan usahanya dengan meniru kegiatanb usaha yang dilakukan oleh pengusaha lain. Kelompok ini menggunakan prinsip ATP (Amati Tiru Plek) tanpa merubah apapun, dan kedua adalah meniru pengusaha lain akan tetapi dengan melakukan modifikasi disana sini.

Berdasarkan hasil penelitian ini terlihat adanya persamaan maupun perbedaan karakteristik yang dimiliki oleh mahasiswa dengan para pengusaha Mitra. Oleh karena itu dalam upaya meningkatkan keterampilan mahasiswa dibidan kewirausahaam, diperlukan model pembelajaraan langsung. Mahasiswa diberi kesempatan untuk terjuan dalam dunia usaha/bisnis dengan mentor para wirausahawan yang ditunjuk. Melalui kegiatan ini nantinya dapat diperoleh gambaran mengenai model-model perencanaan, implementasi, evaluasi, dan pengembangan usaha yang dilakukan oleh para mahasiswa. Dengan demikian rekomendasinya adalah diperlukan penelitian lanjut untuk mendapatkan bahan yang lebih memadai mengenai kewirausahaan dalam praktek. Dengan demikian penyusunan modul pembelajaran kewirausahaan menjadi lebih aplikatif dan tidak teoritis sebagaimana yang ada selama ini.

\section{DAFTAR PUSTAKA}

Drucker,P.F. 1985 Innovetion and entrepreneurship, New York : Happer \& Row.

Faturochman, Fatur. 2000. Penggunaan Informasi Akuntansi dalam Pengelolaan Usaha para Pedagang Kecil di Pasar Tradisional, Laporan DIPA tidak dipublikasikan.

Faturochman, Fatur. 2010. Evaluasi Pelaksanaan Manajemen Audit dalam Rangka Meningkatkan Kinerja Manajemen pada KUKM, Laporan DIPA tidak dipublikasikan.

Gorman, Hanlam dan King (1997) some research perspective on entrepreneur education, enterprise, education and education for small business management. A ten literature review. Int. Small Business.

Upton et al (1995). Have we made differences? An Examination of career activity entrepreneurship major since 1984, Frontiers of Enterpreneurship Reasrch

Charney dan Libercap (2000), the Contribution of enterpreneurship education: An analysis of the berger programme, international Journal of Enterprenewur Education. 
Greene, F.J. and Saridakis, G (2008). The role of higher education skills and support in graduate self-emplyoment, studies in Higher Education, Vol 33, No.6, 653-672.

Kirby, David. 2002 Enterpreneurship. Mc Graw Hill, UK

Pretorius, 2008. Assesment of eneterpreneurship Education: A pilot study. www. Up.ac.za.

Kolb, D 1984. Expreintial Learning: Experiences as the Source of Learning and Development Englewood Cliffs, NJ: Prentice Hall

Rokhayati, Hijroh, dkk (2011), Pengembangan Model Praktik Kerja Program Studi D3 Akuuntasi Terintegrasi dengan UKMK Untuk Peningkatan Soft Skill dan Jiwa Kewirausahaan, Procceding LPPM

Rokhayati, Hijroh dkk (2011), Peningkatan Kinerja UMKM Melalui Perencanan Keuangan dan Manajemen Pembiayaan Yang Efisiensi dan Efektif pada UMKM Gethuk Goreng di Sokaraja, Laporan LPPM tidak dipublikasikan

Rokhayati, Hijroh dkk (2012), Pendampingan UKM dan Pesantern dalam Pengembangan Jejaring Bisnis dengan Pola Inti Plasma, Laporan LPPM tidak dipublikasikan

Schumpeter, J.A. 1934 The theory of economic development, Cambrige, MA: Havard University Press

Setyorini, Diah, 2010. Pengembangan Motivasi Berwirausaha, Penyuluhan Kewirausahaan di Dusun Surobayan, Desa Sumber Rejo, Kecamatan Semin, Gunung Kidul

Suryana. 2006. Kewirausahaan Pedoman Praktis : Kiat dan Proses Menuju Sukses. Penerbit Salemba Empat. Jakarta

Wiranto, Adi. 2007. Analisis Pengaruh Budaya Organisasi dan Lingkungan Organisasi Dan Dimensi Manajerial Enterpreneurship Terhadap Kinerja Finasial pada Usaha Kecil dan Menengah di Kabupaten Banyumas, Laporan DIPA tidak dipublikasikan. 